\title{
THE WAY OF THE YOUNG: FROM \\ REBELLION TO THE THIRST FOR MEANING
}

\author{
Klara Toneva*
}

Abstract: The situation of young people throughout the world, regardless of the culture or nation to which they belong, is becoming more and more alike. Today, they are growing up under the influence of mass culture, media, information overload and the clutter of everyday life. A typical feature of youth culture in Bulgaria is the general dissatisfaction with institutions, whether religious, social or political. This deimitation from the past is quite ambguous: on the one hand, it is indicative of the rebellion against all rules and the established order, while on the other, the very rejection of contemporary social structures and moral values (which, considered within the context of history of religions, signifies also a rejection of history) is distinctly religious in nature. What the young are striving to achieve is to go beyond the world of meanings supplied by parents, school and institutions (including religious institutions) in order to restore the lost meaning of life.

What can Orthodoxy and the Church offer to the young generation of today? Is Orthodoxy a thing of the past or is it the faith of today and tomorrow? This article argues that it is exactly in our time, when many world ideologies are crumbling down, that Orthodoxy is in its prime. Hence follows the responsibility of Orthodox theology, which is, in a language which young people can understand, to find an answer to their key concern:

What is the meaning of our own and of the next century? Keywords: Church, youth culture, institutional rebellion, existential meaning.

\section{Introduction}

I am from the Bulgarian generation, which is a participant in the dramatic events that shook Central and Eastern Europe: the collapse of the political systems of totalitarianism, socialism and of the aggressive atheism. Then came the so desired new time, or stated in a biblical way - came a true divine kairos (favorable time) full of

* PhD, Associate Professor, University of Sofia, Bulgaria. 
anticipation for the change, filled with hope and responsibility in harmony with the words of the apostle: Behold, now is the acceptable time; behold, now is the day of salvation $(2 \operatorname{co~} 6: 2)^{1}$.

After the exaltation and hope, however, came sobering, disappointment and despondency. The transition, which took place in Bulgaria after 10.XI.1989, is from totalitarianism towards democracy and its most important socio-economic consequences, expressed schematically are the following: sharp increase in unemployment; ubiquitous increased emigration from the country; lowered standard of living of the majority of the population; increase in the number of socially disadvantaged people, including wanderers, beggars, homeless; all levels and areas of public life are affected by corruption; the initial political activity of the population is rapidly falling; the majority of the intellectuals distance themselves from the political life, disappointed by the imposition of pseudo-democratic orders and backstage relations; gradual establishment of an economic determinism, which forces people to work and fight (at any cost and by all means necessary) without caring for the needs of our fellows, social environment or nature; uncritical acceptance of the values of the West, mainly in the field of economics, mass culture and lifestyle; young people live with an uncertain future and without a mapped out road in front of them ${ }^{2}$.

After 1990, we, religious Bulgarians had the chance to freely profess our faith and participate in public life as overt Christians but we remained indecisive in our actions, perhaps because the remains of the communist worldview still have a place in our social life: part of the elderly people are torn between the present and their old ideals and thousands of young Bulgarians do not have a formed value

\footnotetext{
${ }^{1}$ Вълчанов, Сл. Библейски и духовни основи на общественото устройство през третото хилядолетие. - В: Църквата в Европа на прага на третото хилядолетие - шансове и предизвикателства. С., 1999, с. 68.

2 See more in Златев, $K$. Икономическото и социалното положение в България - предизвикателство към православната Църква у нас. - В: Църквата в Европа ..., , с. 65-67.
} 
system and stable worldview ${ }^{3}$. Along with the pointed out, the spiritual and moral life of Bulgarians is also being put to the test by non-Christian religious teachings, which offer attractive social programs ${ }^{4}$.

\section{Young people in the heat of everyday life}

The situation of young people around the world, regardless of the cultural and ethnic specifics, is getting increasingly similar. Today they grow up under the strong influence of the so-called mass culture $^{5}$; and through the media, high-speed transfer of information and interpenetration of cultures and religions, they become dependent on the influence of the world. Facing many opportunities, most of which attractive but also dangerous, young people are becoming more and more confused. The contemporary modern school is directed primarily towards offering knowledge, towards huge amount of information, towards creating specialists in certain areas and far less - towards upbringing young people. Religious,

3 More on the religious attitudes among Bulgarians in Серафимова, М. Многоцветната 'картина' на религиозността в българското общество. - В: Библия, Култура, Диалог. Сборник с изследвания и студии. Том I. С., 2009 , с. 267-279; Назърска, Ж., Св. Шапкалова. Ниво на религиозност на православното население в България според данни от православните храмови регистри (1989-2014). - В: сп. „Християнство и култура, 9/2015, c. $77-89$.

4 Киров, Д. Духовно-нравствената ситуация в България - пътища и критерии за практикуване на християнските ценности. - В: Църквите в Европа..., с. 51-52.

5 To the so-called mass culture are dedicated numerous studies of modern thinkers, philosophers, sociologists, culturologists, geo-strategic analysts and others. According to Zbigniew Brzezinski for example the US mass culture exercises influence primarily and especially over young people around the world - American movies and television programs, popular music (Зб. Бжежински. Голямата шахматна дъска. С., 1997, с. 33; вж. също и Фукуяма, Фр. Големият разлом. С., 2001; Иродоту, Сm. Православие и постмодерност. С., 2004, с. 239-293). 
moral and aesthetic enlightenment is replaced by the heat of everyday life, streets and mass media, which appears to be the most important factor in shaping the worldview of the youth.

According to $\mathrm{Hr}$. Yanaras the spiritual void in the contemporary shiny civilization is becoming increasingly apparent. Perhaps perceiving this void will serve as a springboard for dynamic changes ${ }^{6}$. The desacralization of marriage, which is separated from the Eucharist, can undoubtedly be pointed out as a crucial reason for this crisis ${ }^{7}$. The so-called anti-erotic person is formed, who does not want to overcome his selfishness and devote himself to the other. In his marriage such a person is loaded with excessive requirements for receiving and obsession. People expect happiness from marriage and when facing the slightest obstacle find the solution in divorce. Due to careeristic or other reasons marriages are being postponed for an older age, the model of living on a family basis is very widely adopted. The contradictions associated with sexual intercourse is a particularly difficult issue - extramarital sexual relations, extramarital pregnancies - it turns out that this is the example that we the adults, we the parents, give to our children with our behavior. Part of the youth is deprived of parental love and tenderness, they are subjected to harassment at home, in school, even in kindergarten or in orphanages. And vice versa - some families rely on the excessive concern of parents, which is expressed in constant pressure and parental control, consistent criticism, heightened requirements and punishments for minor reasons. So naturally the computer becomes the children's best friend, they spend their free time in front of the $\mathrm{TV}$ watching programs that harm their fragile physical condition. If we leave them to themselves from early childhood, this according to sociologists and psychologists will determine individualism and even individual narcissism as their future most characteristic trait ${ }^{8}$. When

\footnotetext{
${ }^{6}$ Янарас, Хр. Кризата като предизвикателство. С., 2002, с. 171.

7 Радованович, М. Адамов комплекс и Евин синдром. Сп. „Мирна, 15/2001, c. 29.

${ }^{8}$ Бигович, Р. Църква и общество. С., 2003, с. 93-94.
} 
our children grow up they will be convinced that there is no one above the freedom of the individual, that freedom is above solidarity and duty. They will rely on their visual attractiveness, they will idolize their body, they will be captivated by the ideas of independence and individual freedom. Maybe they will be narcissists and gradually turn themselves to gods, because as it is known, hyperindividualism is relentless towards the community and the spirit of the communities ${ }^{9}$.

\section{Young people and religiosity}

Researchers dealing with this problem and mainly with the attitude of young people towards religion point out some discrepancies. On the one hand, young people are open to different religious truths and values, but on the other hand - they are indifferent or hostile towards religious institutions. Generally expressed, the youth is rebelling against the cold authorities: revolting against parental authority (which is conditioned by the severity of parents towards children), against public institutions, against the confined and rough ecclesiastical institutions, then against the shackling systems of thought. And finally - they revolt against the authority of God, either because of the inaccurate notion of Him as a punishing judge, despotic authority or impersonal absolute, or because of the destruction of paternal authority. As a result of the occurring universal feminization man is no longer a spiritual authority neither for the woman as a wife and mother, nor for the children as members of the household church.

The materialistic and consumer culture, which unfortunately also reflects on religious institutions, does not satisfy young people and thus leads to a rift between their language and the language of religious institutions. The fact that young people in Bulgaria are open

9 With reason prof. R. Bigovitch states that along with secularization and pluralism, individualism is the third essential characteristic of postmodernity. Seе Бигович, Р. Църквата в съвременния свят. С., 2013, с. 23. 
to religious mysticism of any kind, to the occult and parapsychological phenomena, with which we are flooded by television programs, to the religious philosophy of Ancient India, and also the fact that they are indifferent to the institutionalized forms of religiosity, speaks plenty about the religious ways of the young. They seek God and possess openness towards the eternal Truth, but, furthermore, tend to follow the modified forms of execution of this religiosity ${ }^{10}$.

What is happening today in the so-called youth culture? Let us start with the pointed out dissatisfaction with existing institutions - religious, ethical, social, political. Such a rupture with the past is existentially contradictory: on the one hand, it is expressed by disapproval and rebellion against all the rules and the so-called order, on the other hand - we have a rejection of the contemporary social structures and moral values. And even this means rejecting civilization and ultimately - history, precisely this rejection brings religious meaning that is clearly detectable for the historian of religions. Proof of that is that among some segments of the youth culture, rediscovery of cosmic religion and the sacred dimension of human existence is observed, and the elements that prove it are for example: unity with nature, sexual spontaneity, desire to live here and now and other. Moreover, interest in the occult, so typical for youth culture, also points to the desire for revival of ancient beliefs and religious ideas (astrology, magic, gnosis, alchemy, orgiastic practices) and for detecting and cultivating non-Christian methods of salvation (Yoga, Tantra, Zen, etc.)

All these quests tell us something very important: when the young are rebelling against the world of significance of the parents,

${ }^{10}$ Бигович, Р. Църква и общество..., с. 94-95. For suppressed polytheism and/or paganism of the modern man of the Western European civilization and culture and its transformation into a psycho-pathological symptoms see in Йеротич, Вл. Завръщане към отците. С., 2013, с. 290. 
authorities, institutions, they are actually fighting to regain the lost meaning, i.e. the meaning of their lives ${ }^{11}$.

"The stronger the power of mass culture, technology and urbanization becomes, says Al. Men, the more acute the individual feels the burden of the new shackles lying on him ... This is why precisely in religion the spirit, lost in the labyrinths of civilization, again and again finds for itself a strong foundation and inner freedom" $"$.

When talking about the relationship between young people and religiosity, we must consider a few facts: first, the youth do not accept religion simply because of tradition, but only if they discover in it the meaning of their lives; and secondly - the young do not tolerate anyone's monopoly over the truth. The categorical rejection of some common civilizational trends that they accept means nothing. It is, therefore, necessary to reveal to them Who is the Truth, but in an understandable way, consistent with their way of thinking and with words (but not moralistic) that they will hear and comprehend.

\section{Orthodoxy and the young people}

Is Orthodoxy a faith of the past, or a faith of today and tomorrow? How in the present, when global ideologies collapse, when the world is shaken by religiously motivated terrorism, can we testify that Orthodoxy is the faith of young people, that exactly it

${ }^{11}$ See in Eлиаде, M. Окултизъм, магия и културна мода, б.г., б.м., с. 102. As noted by Mircea Eliade, to whatever extent desacralization of the world is reached, the man who has chosen the profane life can not abolish religious behavior (Елиаде, М. Сакралното и профанното. С., 1998, с. 15), because the sacred is an element of the structure of the mind, not a stage in the history of the mind (Елиаде, М. Търсенето. История и смисьл в религията. С., 2000, с. 7).

${ }^{12}$ Мен, Ал. Произход на религията. С., 1994, с. 19. 
brings the optimistic, joyful view and joyous sense? Are we aware that through his humanistic nostalgia man is actually groaning for the God-man? ${ }^{13}$ Only Jesus Christ can quench the thirst of the young man - the thirst for meaning, for justice, for truth.

Now, when the human personality is almost devalued by contemporary culture, young people demand respect for their personality. In none of the world's religions is personality raised to such a height as in Christianity. Faith starts from the individual and, of course, leads to mankind, but only by recognizing the unconditional significance of the personality, only after confirming its divine meaning and purpose. If this unconditional value of the separate person is lost, then now or sometime later the care for the personality will be eliminated. And there the darkness of the impersonal spreads; a darkness in which fear, violence, hatred dominate; a darkness, where there is no love. The strongest want for a young person is the need for love and communion and here, albeit unconsciously, is contained the secret of Christian life - love. Orthodoxy finds its deepest dimensions, showing that love is not just a psychological but an ontological feature of each personality ${ }^{14}$.

Sociological studies show that to young people community is a value, which means that they, though unknowingly, are open to the Church, and are open so much more than we think. But is our Church open to them? Because they do not want a Church, which is turned into a national club, into a building, into a closed institution, into a hierarchical class or into a cold organization, which does not differ from other secular organizations.

How can we convince young people that Orthodoxy is not a philosophy, or just a morality, or just an ideology or ritual, but according protopresbyter Al. Schmemann, a gift of new life in Christ $^{15}$; and this new life is the Church?

${ }^{13}$ Попович, И. Православието като философия на живота. С., 2004, с. 107.

${ }^{14}$ Бигович, Р. Църква и общество..., с. 97-98.

${ }^{15}$ Шмеман, Ал. Литургия и живот. Велико Търново, 2002, с. 15. 
How can we show them that Christ is revealed not in our isolation but ... in our unity? ${ }^{16}$ To show our children that the secret of the Church lays in the Holy Mass and that this exact unveiling of the mystery of the Church is the main reason for our every deed, calling, work and ministry in the Church. The Holy Mass is the starting point of every catechization, of the overall education and maturity in faith, and in fact - of all spiritual dimensions of human life and activity ${ }^{17}$.

But here is also the serious problem - what will be the choice of the young man when he has not received Christian education? Unfortunately, even our church schools create more religious rather than ecclesiastical people. If Theology separates from the Church, it becomes a doctrine of rational concepts, a barren fig among many others. The purpose of knowledge is not to present a complete image of existence, but to fully be carried into the truth. To not only be looking at the truth, but to live in it and for it ${ }^{18}$.

Is there another way of change, except the understanding of sacrificial ministry? If young people are educated with a new mindset about the Church, then the changes would occur smoothly and without coercion.

We, the Orthodox theologians in Bulgaria can better utilize our mission only if we know and deeply understand the world, in which we live in, its expectations and aspirations, the deep and rapid changes that occur in it. Then we can answer the young generation in an understandable for them way concerning the eternal question: what is the meaning of this and the future life.

The Christian Mission is always in its beginning - i.e. now, today. It all depends primarily on how much each one of us is a true

\footnotetext{
${ }^{16}$ Прот. Г. Флоровски. Библия. Църква. Предание. Православно гледище. C., 2003, c. 69.

${ }^{17} E n . A m$. Йевтич. Литургийният живот като съдържание на енорийския живот. - В: Църква. Православие. Евхаристия. Кратка антология на съвременното сръбско богословие. Част І. С., 1999, с. 140-142.

18 Прот. Г. Флоровски. Философия и богословие. С., 2012, с. 23.
} 
witness to the joy and peace in the Holy Spirit, a witness to the new life, the meaning of which we find in the Church. And to what extent are we an example, a good example to our children. The responsibility is ours.

\section{Conclusions}

Many of the young Bulgarians do not have a formed value system and a stable worldview because they are becoming more and more confused by the impact of mass culture, technology and excess information. This determines individualism and even individual narcissism as their future most characteristic trait in the absence of the religious, moral and aesthetic education.

Young people rebel against the cold authorities, including against the authority of God, but are open to religious mysticism of any kind. At the same time they seek God and possess openness towards the eternal Truth, but along with that they tend to follow the modified forms of fulfilling their religiosity. Therefore the rebellion of young people is a fight for regaining the lost meaning, i.e. the meaning of their lives.

The strongest want for a young man is the need for love and communion. He can get an answer to the eternal question: what is the meaning of this and the future life through the Mission of the Orthodox theologians, who can with work and ministry educate a new way of thinking about the Church.

\section{References}

1. Бигович, Р. Църква и общество. С., 2003.

2. Бигович, Р. Църквата в съвременния свят. С., 2013.

3. Вълчанов, Сл. Библейски и духовни основи на общественото устройство през третото хилядолетие. - В: Цьрквата в Европа на прага на третото хилядолетие - шансове и предизвикателства. С., 1999.

4. Бжежсински. Голямата шахматна дъска. С., 1997.

5. Елиаде, М. Окултизъм, магия и културна мода, б.г., б.м. 
6. Елиаде, М. Сакралното и профанното. С., 1998.

7. Елиаде, М. Търсенето. История и смисъл в религията. С., 2000.

8. En. Am. Йевтич. Литургийният живот като съдържание на енорийския живот. - В: Църква. Православие. Евхаристия. Кратка антология на съвременното сръбско богословие. Част І. С., 1999.

9. Златев, $K$. Икономическото и социалното положение в България предизвикателство към православната Църква у нас. - В: Църквата в Европа на прага на третото хилядолетие - шансове и предизвикателства. С., 1999.

10. Иродоту, Сm. Православие и постмодерност. С., 2004.

11. Йеротич, Вл. Заврьщане към отците. С., 2013

12. Киров, Д. Духовно-нравствената ситуация в България - пътища и критерии за практикуване на християнските ценности. - В: Църквата в Европа на прага на третото хилядолетие - шансове и предизвикателства. С., 1999.

13. Мен, Ал. Произход на религията. С., 1994.

14. Назърска, Ж., Св. Шапкалова. Ниво на религиозност на православното население в България според данни от православните храмови регистри (1989-2014). - В: сп. „Християнство и култура, 9/2015.

15. Попович, И. Православието като философия на живота. С., 2004.

16. Прот. Г. Флоровски. Библия. Цьрква. Предание. Православно гледище. С., 2003.

17. Прот. Г. Флоровски. Философия и богословие. С., 2012.

18. Радованович, М. Адамов комплекс и Евин синдром. Сп. „Мирна, $15 / 2001$.

19. Серафимова, М. Многоцветната 'картина' на религиозността в българското общество. - В: Библия, Култура, Диалог. Сборник с изследвания и студии. Том I. С., 2009.

20. Шмеман, Ал. Литургия и живот. Велико Търново, 2002.

21. Фукуяма, Фр. Големият разлом. С., 2001.

22. Янарас, Хр. Кризата като предизвикателство. С., 2002. 